\title{
Crop production in relation to cultural practices in the Chromolaena odorata fallow system in South-West Côte d'Ivoire
}

\author{
J.J.P. SLAATS ${ }^{1 *}$, B.H. JANSSEN ${ }^{2}$ AND M. WESSEL ${ }^{1}$ \\ ${ }^{1}$ Department of Agronomy, Wageningen Agricultural University, P.O.Box 341, NL-6700 \\ AH Wageningen, The Netherlands \\ 2 Department of Soil Science and Plant Nutrition, Wageningen Agricultural University, \\ P.O.Box 8005, NL-6700 EC Wageningen, The Netherlands \\ * Corresponding author (present address: CRRA, BP 16, Sikasso, Mali, fax: +223 620349, \\ email: slaats@sik-spgr.ier.ml)
}

Received 25 April 1997; accepted 18 July 1998

\begin{abstract}
Farmers grow food crops alternated by short fallow periods of the naturally re-establishing Chromolaena odorata in response to the growing demand for land in humid Africa. It is unknown whether current cultural practices in this system are appropriate and how land use can further be intensified. Maize production was measured in experiments on three sites cleared from a two-, three- and four-year-old $C$. odorata fallow, respectively. On the two-year-old site, bearing the lowest quantity of vegetation biomass, maize response to removing, burning and intensively burning (i.e.: burning after adding vegetation from outside) the slashed vegetation was studied as well. Various weeding frequencies and fertilizers were applied in the experiments to better assess the effects of the length of the fallow period and the clearing methods. The experiments were conducted during three consecutive cropping seasons to provide an indication of changes in yield over time. During the first season after clearing, maize yield decreased from 3.8 on the four-year-old fallow to $2.6 \mathrm{t} \mathrm{ha}^{-1}$ on the two-year-old fallow. This reduction was due to a lower availability of $\mathrm{P}$ and $\mathrm{N}$, and to a higher competition from weeds. Burning or intensively burning the vegetation raised yields of the unfertilized crop, up to $1.2 \mathrm{t} \mathrm{ha}^{-1}$. It increased the availability of phosphorus but did not clearly reduce competition from weeds. In the second and third season, yield fell to $1.5 \mathrm{t} \mathrm{ha}^{-1}$ irrespective of the fallow age. Burning slowed down the yield decline over time. Application of P- and N-fertilizers raised crop yields under all conditions and maintained them up to $5 \mathrm{t} \mathrm{ha}^{-1}$ during the three seasons. Weeding twice instead of once reduced the yield decline over time on the young fallow only. Results suggest that in the $C$. odorata crop production system a fallow period of two years is too short to be fully effective, that burning the $C$. odorata slash benefits crop production, even when its amount is limited, and that growing maize for more than one season is interesting only where fertilizers are applied.
\end{abstract}

Keywords: burning, Chromolaena odorata, efficiency of nutrient utilization, fallow period, nutrient uptake, prolonged cropping, shifting cultivation alternatives, weed control, Zea mays. 


\section{Introduction}

Intensified land use in humid Africa and Asia has enabled the exotic woody shrub Chromolaena odorata to establish and to dominate the vegetation during the first five years of the fallow period in shifting cultivation (Slaats, 1995). The high demand for land now pushes farmers to grow food crops on land cleared from $C$. odorata. Cultural practices allowing productive and sustainable land use in this short-duration fallow system need to be defined.

For fallows up to 15 years, shortening the fallow period reduces yields of the subsequent crop (Anon., 1993; Lagemann, 1977; De Rouw, 1991; Van Reuler \& Janssen, 1993b). Main causes are more herbaceous weeds being present and fewer nutrients being available at the start of the subsequent cropping period. In the humid tropics, prolonged cropping on land cleared from a forest fallow often results in declining yields because of the decreasing chemical soil fertility (Anon., 1993; Juo \& Kang, 1989; Kang, 1993) and the increasing competition from weeds (Kang et al., 1977; De Rouw, 1991; Sanchez \& Benites, 1987). Burning the slashed fallow vegetation when clearing forested land is generally stated to stimulate crop production. It kills weed seeds in the topsoil and stumps, thus reducing weed development (Ewel et al., 1981; De Rouw \& Van Oers, 1988). It also releases nutrients stored in the fallow vegetation (Nye \& Greenland, 1960; Seubert et al., 1977).

It is unknown whether the short fallow period and the limited amount of slash burnt in the $C$. odorata fallow system effectively reduce weed competition and increase nutrient availability in the subsequent cropping period. The increasing demand for land also calls for options to intensify land use in this system. In the present study the quantitative effects of the length of the fallow period and the management of the slashed fallow vegetation on crop production in the $C$. odorata fallow system were assessed. Results of three subsequent crops gave an indication of changes in these effects over time. Crop responses were studied under various weeding frequencies and fertilizers to distinguish the effects on weed competition from those on nutrient availability.

\section{Materials and methods}

The study area is situated near the village of Taï, in the lowlands of South-West Côte d'Ivoire $\left(5^{\circ} \mathrm{N}, 7^{\circ} \mathrm{W}\right)$ and has a humid tropical climate. Rainfall is bimodally distributed over the period March-October and amounts to an annual mean of $1885 \mathrm{~mm}$ (Collinet et al., 1984). The dry season extends from November to February. Mean monthly temperatures range from $24.7^{\circ} \mathrm{C}$ to $27.4^{\circ} \mathrm{C}$. Experiments were conducted on three sites located at the higher parts of the rolling to undulating landscape. This position is representative of 30 to $50 \%$ of the area (De Rouw et al., 1990), its soils are classified as Ferric Acrisols (Van Reuler, 1996). The sites have similar gravelly, strongly weathered and chemically poor soils. The upper $5 \mathrm{~cm}$ is sandy loam, on top of a 50 to $90 \mathrm{~cm}$ deep layer of sandy clay loam with a high gravel content. The soil below this layer is clayey and contains a small amount of gravel only. 
The three experimental sites were covered by a natural $C$. odorata fallow vegetation. They were former farmers' fields laid fallow since two, three and four years respectively, as indicated by their owners and by the immigrant farmers having grown crops there. They are further referred to as the $2-\mathrm{Y}, 3-\mathrm{Y}$ and $4-\mathrm{Y}$ site. The experiments were carried out during the early cropping season (April-July) and late cropping season (August-November) of 1991, further indicated as 1991-E and 1991-L, and the early cropping season of 1992 (1992-E). On the 3-Y and 4-Y sites the trial was laid down in 4 replicates and had a factorial design, combining two weeding frequencies (one versus two weedings in the cropping season) with three fertilizer treatments (no fertilizer, $\mathrm{P}, \mathrm{P}$ plus $\mathrm{N}$ ). On these sites the slashed fallow vegetation was burnt prior to cropping. On the $2-\mathrm{Y}$ site the trial had a split-plot design and was laid out in five replicates. The main factor was three intensities of clearing: (1) removing the slashed fallow vegetation plus litter, further referred to as 'Removing', (2) burning the slashed fallow vegetation ('Burning'), the prevailing farmers' practice, and (3) burning the slashed vegetation plus the vegetation and litter from treatment (1) ('Intensive Burning'). The sub-plot factors were weeding frequency (one versus two weedings in the cropping season) and fertilizer application (no fertilizers, P, P plus N).

The fallow vegetation of the sites was sampled prior to clearing for determining the dry weight, the nutrient content and the density of stumps of C. odorata and other woody species. The method of sampling is described in Slaats (1995). After sampling, the fallow vegetation on each site was slashed and the trial was laid out. On the $2-Y$ site, the slashed vegetation was raked up in the plots of the 'Removing' treatment and deposited in those of the 'Intensive Burning' treatment. On all sites, burning took place after about one week of drying. Before the 1991-E maize crop was sown, any large unburnt branches were carried out of the field. On plots of the 2-Y site where the slashed vegetation had been removed, the soil was tilled superficially with a short hoe just before sowing. After the harvest, the weed vegetation was slashed and left in situ, burning did not take place and a second maize crop was sown directly. After the second crop had been harvested, the fields were laid fallow during the dry season. At the start of the subsequent cropping season (1992-E), the plots were cleared by slash and burn, according to the method of the first season (1991-E) and maize was sown.

In all the three seasons the hybrid maize variety 'Pioneer 3274 yellow', maturing in 105 days, was sown in rows $(30 \times 60 \mathrm{~cm})$. Weeding was done at 3 and 6 weeks after sowing (WAS) using a short hoe. Phosphorus was applied as triple superphosphate at a rate of $25 \mathrm{~kg} \mathrm{Pha}^{-1}$ at 3 WAS. Nitrogen was applied as urea at a rate of 100 $\mathrm{kg} \mathrm{N} \mathrm{ha}^{-1}$ and was split into equal parts given at 3 and 6 WAS. At harvest, grains, spike plus husks and stover were weighed and sampled. Subsequently, all aboveground parts of the crop were removed from the field.

The crop samples were dried at $70^{\circ} \mathrm{C}$ for 24 hours and weighed. Grains were also dried at $105^{\circ} \mathrm{C}$ to calculate their weight at $14 \%$ moisture. Samples of the twice weeded first season crop, considered the best estimates of the potential nutrient uptake, were chemically analysed according to the standard procedures described by Walinga et al. (1989).

Crop responses to weeding frequency and fertilizer application under different 
clearing treatments were statistically tested by analysis of variance, using the data of the 2-Y site. Responses to weeding frequency and fertilizer application on the normally burnt plots of the three sites were compared as an indication of the effect of the length of the fallow period. Differences in the responses were tested by analysis of variance, considering the experiments as belonging to one split-plot trial with site as main factor and the weeding frequency and fertilizer application treatments as sub-plot factors. The replicates of the three sites were considered as randomly drawn samples without replacement from the three fallow age populations. Strictly spoken, however, statistical evidence just applies to the sites under study and is not necessarily a result of the length of the fallow period only.

\section{Results}

Dry weight, composition and nutrient content of the fallow vegetation

On the 2-Y site, the biomass of $C$. odorata and in particular the amount of litter was lower, whereas the stump density of $C$. odorata was considerably higher than on the 3-Y and 4-Y sites (Table 1). The biomass and stump density of other woody species were particularly high in the $3-Y$ site. In the $2-Y$ and $3-Y$ sites, the average dry weight of herbaceous plants was about $10 \mathrm{~kg} \mathrm{ha}^{-1}$, whereas in the $4-\mathrm{Y}$ site herbs had disappeared. Forbs were most abundant in the 3-Y site, grasses occurred mainly in the $2-Y$ site. The nutrient content of the vegetation grew with increasing fallow period (Table 2).

In both early seasons burning was incomplete on the normally burnt plots in the 2Y site, leaving a soil surface with a mosaic of black patches and patches that had hardly been touched by the fire. The quantity of fallow vegetation biomass was visibly too small to allow a good spread of the fire. On the plots of the 2-Y site where a double amount of fallow vegetation was burnt ('Intensive Burning') as well as on the 3- and 4-Y sites, burning was more complete and resulted in an uniformly blackened soil surface. By carrying away the unburnt woody material from the field before sowing, 4 to $13 \%$ of the nutrients accumulated in the vegetation were removed, except for the proportion of calcium on the $4-Y$ site reaching $20 \%$ (Table 2).

Table 1. Dry weight of the total above-ground biomass and stump density of woody species in the $C$. odorata fallow vegetation in three sites differing in the length of the preceding fallow period.

\begin{tabular}{|c|c|c|c|c|c|c|}
\hline \multirow[t]{2}{*}{ Site } & \multirow{2}{*}{$\begin{array}{l}\text { Fallow } \\
\text { period } \\
\text { (year) }\end{array}$} & \multicolumn{3}{|c|}{ Dry weight $\left(\mathrm{t} \mathrm{ha}^{-1}\right)$} & \multicolumn{2}{|c|}{ Stump density $\left(\right.$ no. $\mathrm{m}^{-2}$ ) } \\
\hline & & C. odorata & $\begin{array}{l}\text { Other woody } \\
\text { species }\end{array}$ & Litter & C. odorata & $\begin{array}{l}\text { Other woody } \\
\text { species }\end{array}$ \\
\hline $2-\mathrm{Y}$ & 2 & $9.6 \pm 0.5^{\mathrm{a}}$ & $3.3 \pm 0.6$ & $1.5 \pm 0.1$ & $17.1 \pm 3.2$ & $5.8 \pm 0.7$ \\
\hline $3-\mathrm{Y}$ & 3 & $10.3 \pm 0.9$ & $6.6 \pm 1.2$ & $3.2 \pm 0.4$ & $4.8 \pm 1.3$ & $14.8 \pm 4.6$ \\
\hline $4-\mathrm{Y}$ & 4 & $11.5 \pm 0.7$ & $3.8 \pm 1.0$ & $6.4 \pm 0.3$ & $7.7 \pm 0.9$ & $2.0 \pm 0.2$ \\
\hline
\end{tabular}

${ }^{a}$ standard error of the mean 
Table 2. Nutrient content of the above-ground biomass plus litter in the $C$. odorata fallow vegetation and the proportion of nutrients removed by carrying away the unburnt remnants after burning the slashed vegetation in three sites differing in the length of the preceding fallow period.

\begin{tabular}{|c|c|c|c|c|c|c|}
\hline Site & $\begin{array}{l}\text { Fallow period } \\
\text { (year) }\end{array}$ & $\mathrm{N}$ & $\mathrm{P}$ & $\mathrm{K}$ & $\mathrm{Ca}$ & $\mathrm{Mg}$ \\
\hline & & \multicolumn{5}{|c|}{ Nutrient uptake $\left(\mathrm{kg} \mathrm{ha}^{-1}\right)$} \\
\hline $2-\mathrm{Y}$ & 2 & $70.7 \pm 5.1^{\mathrm{a}}$ & $5.0 \pm 0.2$ & $109.3 \pm 3.8$ & $69.6 \pm 3.9$ & $27.6 \pm 0.9$ \\
\hline $3-\mathrm{Y}$ & 3 & $84.7 \pm 6.4$ & $6.8 \pm 0.3$ & $130.2 \pm 6.0$ & $102.6 \pm 8.5$ & $35.2 \pm 1.6$ \\
\hline \multirow[t]{2}{*}{$4-Y$} & 4 & $44.6 \pm 13.6$ & $8.2 \pm 0.7$ & $127.8 \pm 10.7$ & $136.6 \pm 11.8$ & $42.7 \pm 2.2$ \\
\hline & \multicolumn{6}{|c|}{ Calculated ${ }^{\mathrm{b}}$ nutient removal ( $\%$ of nutrient content) } \\
\hline $2-\mathrm{Y}$ & 2 & 5 & 4 & 5 & 5 & 4 \\
\hline $3-\mathrm{Y}$ & 3 & 9 & 10 & 9 & 12 & 7 \\
\hline $4-Y$ & 4 & 10 & 10 & 12 & 20 & 13 \\
\hline
\end{tabular}

a standard error of the mean

${ }^{\mathrm{b}}$ weight of remnants times nutrient fraction determined before burning

\section{Crop yields}

On all three experimental sites, application of $\mathrm{P}$ and $\mathrm{P}$ plus $\mathrm{N}$ gave significant gains in yield throughout the experiment. In the first season, yield increase upon application of $\mathrm{P}$ was significantly higher on the 4-Y site than on the 2-Y site, while the increment attributable to the application of $\mathrm{N}$ was significantly higher on the 2-Y site than on the older sites (Figure 1a). In the following two seasons, yield increments as result of fertilizer application were similar on the three sites. Interactions between weeding and fertilizer treatments were not significant. During the three seasons, weeding twice instead of once raised the average yield (Figure 1b). The increment tended to be higher on the 2-Y site than on the 3-Y and 4-Y sites, but this interaction was statistically significant in the third season only. Over the seasons, yields dropped to similar values on all sites independent from the weeding frequency. Applying fertilizers significantly reduced yield decline over time, but not similarly on all sites. Most pronounced was the difference between the substantial reduction in yield decline on the 3-Y site and the slight reduction on the 2-Y site following the application of $\mathrm{N}$ and $\mathrm{P}$.

On the 2-Y site, a significant interaction between clearing method and fertilizer application was found for the three seasons (Figure 1c). Yields of the unfertilized crop were higher after burning and intensively burning the fallow vegetation than after removing it. Upon fertilizer application, yields were similar for all clearing treatments. Two responses deserve particular attention: $\mathrm{P}$ application during the first season gave a significantly higher yield in the 'Removing' treatment than in both burning treatments; application of $\mathrm{N}$ and $\mathrm{P}$ during the third season gave a significantly lower yield in the 'Removing' treatment than in both burning treatments. Weeding twice instead of once raised the average yield in the three seasons (Figure 1d). This 

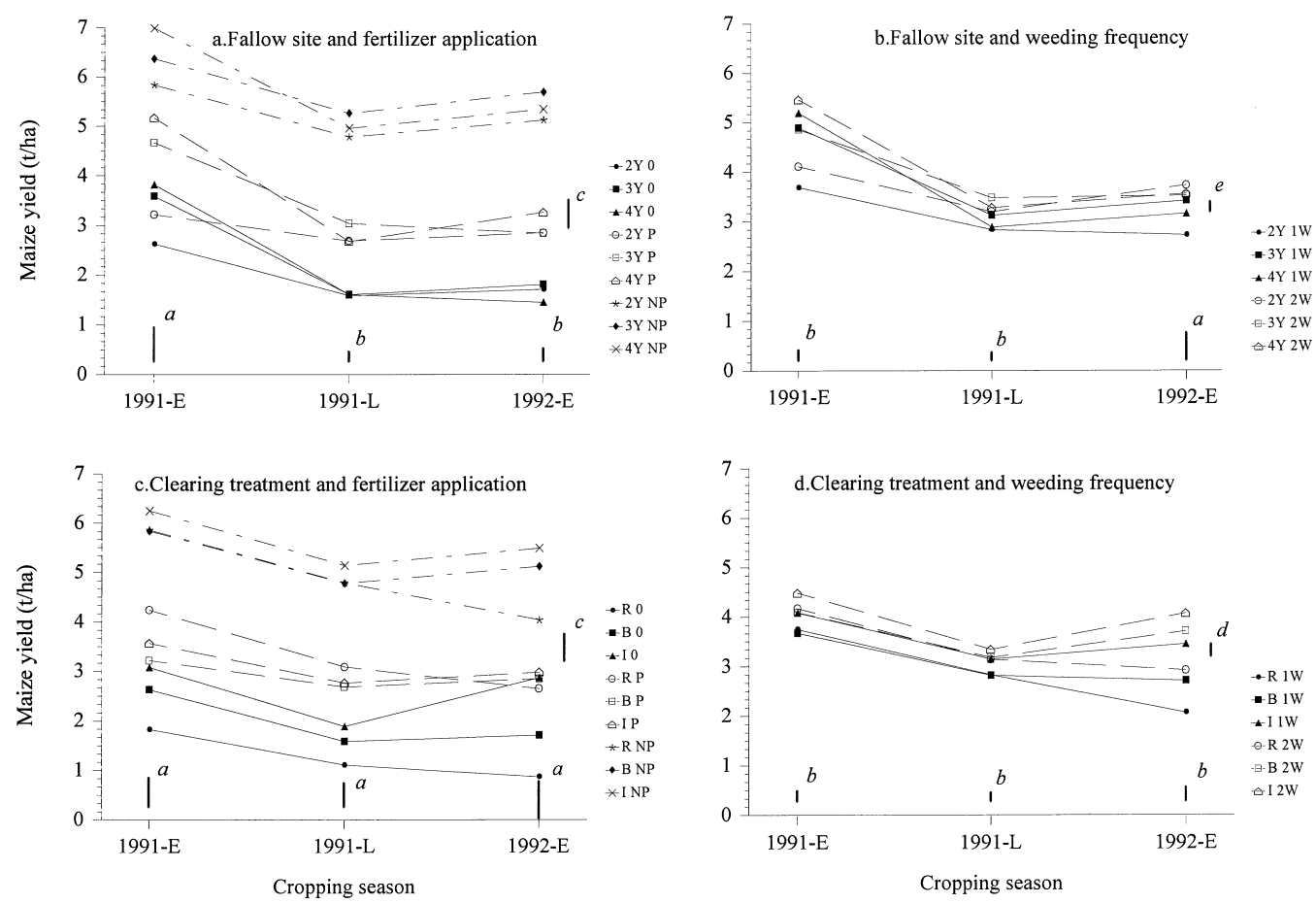

Figure 1. Effects of fertilizer application and weeding frequency on maize yields $\left(\mathrm{t} \mathrm{ha}^{-1}\right)$ during the three seasons following clearing of the $C$. odorata fallow vegetation in three sites differing in the length of the preceding fallow period $(\mathrm{a}, \mathrm{b})$ and in one site cleared according to three different methods (c, d). Vertical bars indicate LSD $(P<0.05)$ for $(a)$ interaction between site $(\mathrm{T})$ or clearing treatment $(\mathrm{C})$ and weeding frequency $(\mathrm{W})$ of fertilizer application $(\mathrm{F})$ within a season, $(b)$ differences between averages of $\mathrm{W}$ or $\mathrm{F}$ within a season (in case $a$ not significant), $(c)$ interaction between $\mathrm{T}$ or $\mathrm{C}, \mathrm{F}$ and season $(\mathrm{S}),(d)$ interaction between averages per $\mathrm{W}$ and $\mathrm{S}$ (in case $c$ not significant), (e) differences of overall yield per season (in case $c$ and $d$ not significant).

increase was more pronounced in the third season than in the first and second season. Interactions between weeding frequency and clearing method as well as those between weeding frequency and fertilizer application were not significant. Over the seasons, yields dropped most for the 'Removal' treatment and least for the 'Intensive Burning' treatment. Fertilizer application reduced the fall in yield for the 'Burning' treatment, while enhancing it for the 'Removal' and 'Intensive Burning' treatments, the difference being statistically significant. Weeding twice instead of once significantly reduced the drop in yields, but this effect was similar for all clearing methods.

\section{Nutrient uptake}

On the normally burnt plots of the $2-\mathrm{Y}$ site, the average uptake of $\mathrm{N}, \mathrm{P}$ and $\mathrm{K}$ was significantly lower than on those of the $3-\mathrm{Y}$ and $4-\mathrm{Y}$ sites (Table 3). Application of 
$\mathrm{P}$ and NP substantially increased the $\mathrm{P}$ and $\mathrm{N}$ content of the crop and also enhanced the uptake of K. Interactions between fertilizer application and site were not significant.

The concept of efficiency of utilization (EU) of the absorbed nutrients was used to interpret nutrient availability relative to other growth factors. EU is defined as grain yield (14\% moisture) per unit nutrient absorbed by the crop. According to Janssen et al. (1990), maize grain yields increase maximally by $70 \mathrm{~kg}$ per $\mathrm{kg} \mathrm{N}, 600 \mathrm{~kg}$ per $\mathrm{kg} \mathrm{P}$ and $120 \mathrm{~kg}$ per $\mathrm{kg} \mathrm{K}$ absorbed. Minimum values, indicating nutrient accumulation in the crop, are 30, 200 and $30 \mathrm{~kg}$ grain per $\mathrm{kg} \mathrm{N}, \mathrm{P}$ and $\mathrm{K}$, respectively.

The average efficiency of utilization (EU) of $\mathrm{N}$ was significantly higher on the 2$\mathrm{Y}$ site than on the 3-Y site, and the EU of $\mathrm{P}$ was significantly higher for 3-Y site than on the 4-Y site (Table 3). On all sites fertilizer application had a pronounced effect on the averaged EU of the three elements. When only $\mathrm{P}$ was applied, the average EU of $\mathrm{N}$ increased whereas the average EU of $\mathrm{P}$ dropped significantly. Applying both $\mathrm{N}$ and $\mathrm{P}$ substantially increased the average $\mathrm{EU}$ of $\mathrm{P}$ and $\mathrm{K}$ whereas it reduced that of N.

As to the clearing methods, 'Intensive Burning' significantly increased the P-uptake by the first crop (Table 4). Interactions between clearing method and fertilizer

Table 3. Effect of fertilizer application on the uptake of nutrients and on the efficiency of their utilization in maize (grain and stover) on plots weeded twice during the first season after clearing the C. odorata fallow vegetation on three sites differing in the length of the preceding fallow period.

\begin{tabular}{|c|c|c|c|c|c|c|c|c|c|c|}
\hline \multirow{3}{*}{ Nutrient } & \multirow{3}{*}{ Site } & \multirow{3}{*}{$\begin{array}{l}\text { Fallow } \\
\text { period } \\
\text { year) }\end{array}$} & \multicolumn{4}{|c|}{ Nutrient uptake $\left(\mathrm{kg} \mathrm{ha}^{-1}\right)$} & \multicolumn{4}{|c|}{ EU (kg grain/kg nutrient uptake) } \\
\hline & & & \multicolumn{3}{|c|}{ Fertilizer application } & \multirow{2}{*}{$\begin{array}{l}\text { Average } \\
\text { uptake }\end{array}$} & \multicolumn{3}{|c|}{ Fertilizer application } & \multirow{2}{*}{$\begin{array}{l}\text { Average } \\
\text { EU }\end{array}$} \\
\hline & & & 0 & $\mathrm{P}$ & NP & & 0 & $\mathrm{P}$ & NP & \\
\hline \multirow[t]{5}{*}{$\mathrm{N}$} & $2-\mathrm{Y}$ & 2 & 48.7 & 48.2 & 105.0 & 67.3 & 63 & 76 & 61 & 67 \\
\hline & $3-Y$ & 3 & 73.7 & 79.0 & 125.2 & 92.6 & 52 & 62 & 54 & 56 \\
\hline & $4-\mathrm{Y}$ & 4 & 71.0 & 86.8 & 135.5 & 97.7 & 56 & 67 & 56 & 60 \\
\hline & Average $^{a}$ & & 62.9 & 69.0 & 120.2 & & 58 & 69 & 58 & \\
\hline & $\operatorname{LSD}(0.05)$ & & & $12.4^{\mathrm{b}}$ & & $17.4^{\mathrm{c}}$ & & $7^{\mathrm{b}}$ & & $11^{\mathrm{c}}$ \\
\hline \multirow[t]{5}{*}{$\mathrm{P}$} & $2-\mathrm{Y}$ & 2 & 5.5 & 8.9 & 11.7 & 8.7 & 544 & 384 & 551 & 493 \\
\hline & $3-Y$ & 3 & 6.4 & 11.4 & 13.4 & 10.4 & 640 & 421 & 494 & 518 \\
\hline & $4-Y$ & 4 & 7.8 & 15.7 & 16.9 & 13.5 & 513 & 335 & 439 & 436 \\
\hline & Average & & 6.5 & 11.7 & 13.8 & & 563 & 387 & 500 & \\
\hline & $\operatorname{LSD}(0.05)$ & & & $1.7^{\mathrm{b}}$ & & $1.4^{\mathrm{c}}$ & & $86^{\mathrm{b}}$ & & $57^{\mathrm{c}}$ \\
\hline \multirow[t]{5}{*}{ K } & $2-Y$ & 2 & 45.7 & 65.3 & 87.7 & 66.2 & 63 & 51 & 72 & 62 \\
\hline & $3-Y$ & 3 & 106.2 & 93.1 & 103.7 & 101.0 & 33 & 51 & 66 & 50 \\
\hline & $4-Y$ & 4 & 64.7 & 107.5 & 115.4 & 95.9 & 58 & 54 & 65 & 59 \\
\hline & Average & & 69.5 & 86.3 & 100.8 & & 53 & 52 & 68 & \\
\hline & $\operatorname{LSD}(0.05)$ & & & $16.7^{\mathrm{b}}$ & & $24.4^{\mathrm{c}}$ & & $9^{b}$ & & $\mathrm{~ns}^{\mathrm{c}}$ \\
\hline
\end{tabular}

${ }^{a}$ weighted average taking into account the number of replicates per site

${ }^{\mathrm{b}}$ LSD for differences between fertilizer treatments averaged over all sites

${ }^{\mathrm{c}}$ LSD for differences between sites averaged over all fertilizer treatments 
Table 4. Effect of clearing methods and fertilizer application on the uptake of nutrients and on the efficiency of their utilization in maize (grain and stover) on plots weeded twice during the first season after clearing a two-year-old $C$. odorata fallow.

\begin{tabular}{|c|c|c|c|c|c|c|c|c|c|}
\hline \multirow{3}{*}{ Nutrient } & \multirow{3}{*}{ Clearing method } & \multicolumn{4}{|c|}{ Nutrient uptake $\left(\mathrm{kg} \mathrm{ha}^{-1}\right)$} & \multicolumn{4}{|c|}{ EU (kg grain/kg nutrient uptake) } \\
\hline & & \multicolumn{3}{|c|}{ Fertilizer application } & \multirow{2}{*}{$\begin{array}{l}\text { Average } \\
\text { uptake }\end{array}$} & \multicolumn{3}{|c|}{ Fertilizer application } & \multirow{2}{*}{$\begin{array}{l}\text { Average } \\
\text { EU }\end{array}$} \\
\hline & & 0 & $\mathrm{P}$ & NP & & 0 & $\mathrm{P}$ & NP & \\
\hline \multirow[t]{5}{*}{$\mathrm{N}$} & Removing & 49.1 & 71.2 & 113.1 & 77.8 & 46 & 67 & 56 & 56 \\
\hline & Burning & 48.7 & 48.2 & 105.0 & 67.3 & 63 & 76 & 61 & 67 \\
\hline & Intensive burning & 48.3 & 61.2 & 118.6 & 76.0 & 72 & 66 & 58 & 66 \\
\hline & Average & 48.7 & 60.2 & 112.2 & & 60 & 70 & 59 & \\
\hline & $\operatorname{LSD}(0.05)$ & & $8.4^{\mathrm{a}}$ & & $\mathrm{ns}^{\mathrm{b}}$ & & $8^{\mathrm{a}}$ & & $8^{\mathrm{b}}$ \\
\hline \multirow[t]{5}{*}{$\mathrm{P}$} & Removing & 4.0 & 12.0 & 13.5 & 9.8 & 570 & 386 & 463 & 473 \\
\hline & Burning & 5.5 & 8.9 & 11.7 & 8.7 & 544 & 384 & 551 & 493 \\
\hline & Intensive burning & 6.6 & 12.1 & 15.9 & 11.5 & 523 & 320 & 429 & 424 \\
\hline & Average & 5.4 & 11.0 & 13.7 & & 546 & 364 & 481 & \\
\hline & $\operatorname{LSD}(0.05)$ & & $1.2^{\mathrm{a}}$ & & $1.7^{\mathrm{b}}$ & & $74^{\mathrm{a}}$ & & $52^{\mathrm{b}}$ \\
\hline \multirow[t]{5}{*}{ K } & Removing & 40.1 & 80.8 & 91.0 & 70.6 & 53 & 58 & 69 & 60 \\
\hline & Burning & 45.7 & 65.3 & 87.7 & 66.2 & 63 & 51 & 72 & 62 \\
\hline & Intensive burning & 52.6 & 81.6 & 106.1 & 80.1 & 61 & 46 & 65 & 58 \\
\hline & Average & 46.1 & 75.9 & 94.9 & & 59 & 52 & 69 & \\
\hline & $\operatorname{LSD}(0.05)$ & & $9.7^{\mathrm{a}}$ & & $\mathrm{ns}^{\mathrm{b}}$ & & $5^{\mathrm{a}}$ & & $\mathrm{ns}^{\mathrm{b}}$ \\
\hline
\end{tabular}

${ }^{a}$ LSD for differences between fertilizer treatments averaged over all clearing methods

${ }^{\mathrm{b}}$ LSD for differences between clearing methods averaged over all fertilizer treatments

application were not significant, although the nutrient uptake of the fertilized crop seemed lower in the 'Burning' treatment than in the 'Removing' and 'Intensive Burning' treatments. The average nutrient uptake over all clearing methods was significantly higher when fertilizers were applied.

'Burning' and 'Intensive Burning' increased the EU of $\mathrm{N}$ in the first crop (Table 4). On the other hand, 'Intensive Burning' gave a lower EU of P than 'Burning'. The EU of $\mathrm{K}$ was not significantly affected by the method of clearing, either was there a significant interaction between fertilizer application and clearing method. Fertilizer application affected the averaged EU of the three elements in the same way as on the sites varying in fallow age.

\section{Discussion}

\section{Length of the fallow period}

The characteristics of the fallow vegetation on the three sites corresponded to the development of the $C$. odorata vegetation over time described in an earlier study (Slaats et al., 1996). The stagnating amount of above-ground $C$. odorata biomass 
and the high amount of litter on the site cleared from a four-year-old fallow indicate the decline of $C$. odorata. The older the fallow vegetation, the more grasses and forbs in the undergrowth had disappeared, the number of $C$. odorata stumps had fallen and nutrients had accumulated in the vegetation. The three-year-old vegetation did not completely fit into this development pattern. It contained relatively few $C$. odorata plants and many of other woody species, and it had hardly accumulated more $\mathrm{N}$ than the two-year-old vegetation.

On the site cleared from a two-year-old fallow, a second weeding tended to increase crop yield and to maintain this at a higher level when cropping was extended. On sites cleared from older fallow, this effect was not observed. These findings suggest that weed competition with the crop was enhanced by shortening the fallow period. The more pronounced weed competition might be related to the high number of C. odorata stumps and the presence of grasses in the fallow vegetation on the particular site. As the stumps sprout easily after clearing and grow rapidly, they probably compete with the crop. Grasses in the undergrowth of the fallow vegetation indicate the presence of soilborne seeds which will emerge after clearing (Saxena \& Ramakrishnan, 1984). Extending the fallow period is likely to reduce the seed bank of grasses, as reported by Staver (1991) for a bush fallow in Peru.

The longer a site had been laid fallow, the higher the maize yield obtained during the first season after clearing. This effect is most likely due to the increased availability of $\mathrm{P}$ and $\mathrm{N}$, as indicated by the high dilution of these elements in the plant and by the crop responses to fertilizer application. Gichuru (1991) also reported a positive relationship between $\mathrm{N}$ availability and crop yield on young fallows in southeastern Nigeria. On the sites cleared from older fallow, more P accumulated in the vegetation and becomes available for crop growth after clearing and burning. Most of the $\mathrm{N}$ accumulated in the fallow vegetation is probably volatilized at burning. In studies dealing with slash-and-burn of a forest vegetation losses vary from 60 to $90 \%$ (Ewel et al., 1981; Van Reuler \& Janssen, 1993a). The limited N supply on the site cleared from a two-year-old fallow, in particular upon application of $\mathrm{P}$-fertilizer, is probably due to immobilization of soil $\mathrm{N}$. The slashed vegetation on this site was not burnt completely leaving mainly woody material unburnt. This material supposedly has a high $\mathrm{C}: \mathrm{N}$ ratio, well above the range of 30 to 100 reported for C. odorata leaves (Agbim, 1987; Obatolu \& Agboola, 1993). Immobilisation of $\mathrm{N}$ being stimulated by adding fertilizer-P was also reported in a laboratory experiment with litter gathered under a forest cover in the Taï region (Braakhekke et al., 1993).

On the sites cleared from older fallows crop yields were higher in the first season only, thus showing that the increased availability of nutrients was short-living. The finding also suggests that the sites did not differ substantially in inherent soil fertility.

The results of the present study indicate that two years of fallow are insufficient to effectively reduce weed competition in the $C$. odorata crop production system. Such a short period also limits the amounts of nutrients being available to the subsequent crop in case no fertilizers are given. 


\section{Clearing treatments}

For all clearing methods alike, an extra weeding gave higher crop yield. This finding indicates that either of the two burning treatments reduced weed growth to such extent that it did not compete with the crop. In another experiment, burning and intensively burning the slashed $C$. odorata vegetation prior to cropping reduced the number of $C$. odorata seedlings by $80 \%$ and the number of sprouting stumps of the same species at three weeks after clearing by 50 and $80 \%$, respectively (Slaats, 1995). This finding suggest that the decreased weed growth following intensive burning might allow to postpone the first weeding and consequently reduce the effect of the second weeding.

Burning the slashed fallow vegetation is an effective method to increase the availability of $\mathrm{P}$, as indicated by an increase in yield and P-uptake, and by a less efficient utilization of $\mathrm{P}$ in the unfertilized crop during the first season. Presumably, burning also slightly raised the $\mathrm{pH}$ of the soil, which according to van Reuler \& Janssen (1993b) improves the utilization of absorbed P. Increasing the amount of vegetation to be burnt (treatment 'Intensive Burning') raised the uptake of P. It results in a higher proportion of $\mathrm{P}$ being released as shown in another experiment conducted in the same region (Slaats, 1995). Crop responses during the third season confirm the importance of burning on nutrient availability.

On the burnt plots, in particular when P-fertilizer was applied, the poor availability of $\mathrm{N}$ limited crop yield of the first season as indicated by the low uptake and the high efficiency of utilization of this element. Since other clearing treatments gave higher yields, it is improbable that the deficiency in $\mathrm{N}$ was caused by volatilization or removal of this element stored in the vegetation. More likely, $\mathrm{N}$ deficiency on the burnt plots is due to immobilization of soil $\mathrm{N}$ following the incomplete burning as discussed above. Yields of the third season being similar for the unfertilized and the P-fertilized crop suggest that burning did no longer affect the availability of $\mathrm{N}$. Probably, the slashed vegetation which mainly consisted of young leafy material was readily decomposed without immobilizing $\mathrm{N}$, if it had not been burnt completely.

The effect of clearing methods on nutrient availability is short-living as shown by the similar crop responses in the second cropping season when the slashed vegetation had not been burnt prior to cropping.

Summarizing, burning the limited amount of slash when clearing land under a young $C$. odorata fallow effectively increases P-availability for crop production. Doubling the amount of slash gives a more uniform burning and further increase in crop yield and availability of P. However, this alternative is not recommended as the additional crop yield probably does not offset the higher land and labour requirements.

\section{Prolonged cropping}

Extending the cropping period reduced yields on all experimental sites. This decrease was slowed down upon application of P- and N-fertilizers, confirming the conclusion of earlier referred studies that yields are maintained when these nutrients 
are available. Burning the slashed fallow vegetation had a similar effect on yield decline, probably because it raises the $\mathrm{pH}$ of the topsoil and leads to cations incorporated in the fallow vegetation being released. Weed competition was more serious when cropping was prolonged, but caused yields to drop over time on the site cleared from a two-year-old fallow only. When cropping on cleared $C$. odorata fallow was prolonged beyond three seasons, as done in another experiment, yields dropped to $0.3 \mathrm{t} \mathrm{ha}^{-1}$ and could no longer be maintained by applying $\mathrm{N}$ and P-fertilizer (Slaats, 1995). According to Van Reuler (1996), extending cropping periods on forest soils in the Taï region leads to declining yields and less efficient utilization of the absorbed $\mathrm{P}$, even when $\mathrm{N}$ - and $\mathrm{K}$-fertilizers were applied. These findings suggest that other factors than the availability of $\mathrm{N}$ and $\mathrm{P}$ play a role in declining yields over time. In our study degradation of soil properties is likely since crop residues had been removed after each harvest.

Yields of the second crop, grown during the late season, were lower than could be expected by interpolation of the yields of the first and third crop both grown in the early season. This demonstrates that conditions for growing maize were less adequate in the late season, probably because of the lower radiation and the shorter period of rainfall (Collinet et al., 1984).

In summary, extending cropping periods for maize production in the $C$. odorata fallow system has limited prospects beyond the first season for a non-fertilized crop.

Finally, the significant yield increase with fertilizer application throughout the duration of the experiments clearly indicates that $\mathrm{P}$ restricts crop production on $C$. odorata fallows, and that $\mathrm{N}$ becomes limiting when $\mathrm{P}$ fertilizer is given. The deficiencies are furthermore shown in the high utilization efficiencies of both elements in the crop. It confirms findings of soil fertility experiments carried out in the region (Van Reuler, 1996). In humid tropical Africa, deficiencies of $\mathrm{N}$ and $\mathrm{P}$ in crop production on fallow clearings are common, particularly when fallow periods are short and cropping is prolonged (Kang et al., 1977; Nye \& Greenland, 1960).

\section{Acknowledgement}

We thank the Ministry of Scientific Research in Côte d'Ivoire for the permission to carry out this study. We acknowledge the field staff for their assistance in data collection.

\section{References}

Agbim, N.N., 1987. Carbon cycling under Chromolaena odorata (L.) K.\& R. canopy. Biological Agriculture and Horticulture 4: 203-212.

Anonymous, 1993. Annual report. International Centre for Research in Agroforestry (ICRAF), Nairobi, $208 \mathrm{pp}$.

Braakhekke, W.G., H.A. Stuurman, H. Van Reuler \& B.H. Janssen, 1993. Relations between nitrogen and phosphorus immobilization during decomposition of forest litter. In: M.A.C. Fragoso \& M.L. Van 
Beusichem, (Eds). Optimization of plant nutrition. Kluwer Academic Publishers, Dordrecht, pp. 117-123.

Collinet, J., B. Monteny \& B. Pouyaud, 1984. Le milieu physique. In: J.L. Guillaumet, G.Couturier \& H. Dosso, (Eds). Recherche et aménagement en milieu forestier tropical humide: le Projet Taï. UNESCO, Notes techniques du MAB 15. UNESCO, Paris, pp. 35-59.

De Rouw, A. 1991. Rice, weeds and shifting cultivation in a tropical rain forest - A study of vegetation dynamics. PhD Thesis, Wageningen Agricultural University, Wageningen, $263 \mathrm{pp}$.

De Rouw, A., \& C. Van Oers, 1988. Seeds in rain forest soil and their relation to shifting cultivation in Ivory Coast. Weed Research 28: 373-381.

De Rouw, A., H.C. Vellema \& W.A. Blokhuis, 1990. A land unit survey of the Taï region, South-West Côte d'Ivoire. Tropenbos Technical Series 7. The Tropenbos Foundation, Ede, 222 pp.

Ewel, J., B. Berish, B. Brown, N. Price \& J. Raich, 1981. Slash and burn impacts on a Costa Rican wet forest site. Ecology 62: 816-829.

Gichuru, M.P., 1991. Residual effects of natural bush, Cajanus cajan and Tephrosia candida on the productivity of an acid soil in southeastern Nigeria. Plant and Soil 134: 31-36.

Janssen, B.H., F.C.T. Guiking, D. Van der Eijk, E.M.A. Smaling, J. Wolf \& H. Van Reuler, 1990. A system for quantitative evaluation of the fertility of tropical soils (QUEFTS). Geoderma 6: 299-318.

Juo, A.S.R. \& B.T. Kang, 1989. Nutrient effects of modification of shifting cultivation in West Africa. In: J. Proctor, (Ed.). Mineral nutrients in tropical forest and savanna ecosystems. Special Publication 9 of the British Ecological Society, Blackwell Scientific Publications, Oxford, pp. 289-300.

Kang, B.T., 1993. Changes in chemical soil properties and crop performance with continuous cropping on an Entisol in the humid tropics. In: K. Mulongoy \& R. Merckx, (Eds). Soil organic matter dynamics and sustainability of tropical agriculture. Proceedings of an international symposium, Leuven, 4-6 November 1991. John Wiley \& Sons, New York, pp. 297-305.

Kang, B.T., F. Donkoh \& K. Moody, 1977. Soil fertility management on benchmark soils in the humid low altitude tropics of West Africa. Agronomy Journal 69: 651-656.

Lagemann, J., 1977. Traditional African farming systems in Eastern Nigeria - An analysis of reaction to the increased population pressure. Afrika Studien 98, Weltforum Verlag, München, 269 pp.

Nye, P.H. \& D.J. Greenland, 1960. The soil under shifting cultivation. Technical Communication 51. Commonwealth Bureau of Soils, Farnham Royal, 156 pp.

Obatolu, Ch. R. \& Agboola, A. A., 1993. The potential of Siam weed (Chromolaena odorata) as a source of organic matter for soils in the humid tropics. In: K. Mulongoy \& R. Merckx, (Eds). Soil organic matter dynamics and sustainability of tropical agriculture. Proceedings of an international symposium, Leuven, 4-6 November 1991. John Wiley \& Sons, New York, pp. 94-99.

Sanchez, P.A. \& J.R. Benites, 1987. Low-input cropping for acid soils in the humid tropics. Science 238: $1521-1527$.

Saxena, K.G. \& P.S. Ramakrishnan, 1984. Herbaceous vegetation development and weed potential in slash and burn agriculture (Jhum) in northeastern India. Weed Research 24: 135-142.

Seubert, C.E., P.A. Sanchez \& C. Valverde, 1977. Effects of land clearing methods on soil properties and crop performance in an Ultisol of the Amazon Jungle of Peru. Tropical Agriculture (Trinidad) 54: 307-321.

Slaats, J.J.P. 1995. Chromolaena odorata in food cropping systems. An agronomic assessment in SouthWest Ivory Coast. PhD Thesis, Wageningen Agricultural University, Wageningen, 177 pp.

Slaats, J.J.P., W.M. Van der Heiden, C.M. Stockmann, M. Wessel \& B.H. Janssen, 1996. Growth of the Chromolaena odorata fallow vegetation in semi-permanent food crop production systems in SouthWest Côte d'Ivoire. Netherlands Journal of Agricultural Science 44: 179-192.

Staver, C., 1991. The role of weeds in the productivity of Amazonian bush fallow agriculture. Experimental Agriculture 27: 287-304.

Van Reuler, H. 1996. Nutrient management over extended cropping periods in the shifting cultivation system of south-west Côte d'Ivoire. Tropical Resource Management Paper 12, Wageningen Agricultural University, Wageningen, 189 pp.

Van Reuler, H. \& B.H. Janssen, 1993a. Nutrient fluxes in the shifting cultivation system of South-West Côte d'Ivoire. I.Dry matter production, nutrient contents and nutrient release after slash and burn for two fallow vegetations. Plant and Soil 154: 169-177.

Van Reuler, H. \& B.H. Janssen, 1993b. Nutrient fluxes in the shifting cultivation system of the Taï- 
region, South-West Côte d'Ivoire. II. Short-term and long-term effects of burning the slashed vegetation on the yield and nutrient uptake of food crops. Plant and Soil 154: 179-188.

Walinga, I., W. Van Vark, V.J.G. Houba \& J.J. Van der Lee, 1989. Soil and plant analysis. Part 7: Plant analysis procedures. Department of Soil Science and Plant Nutrition, Wageningen Agricultural University, Wageningen, $263 \mathrm{pp}$. 